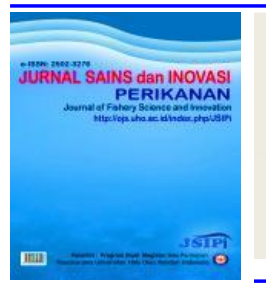

\title{
Hubungan Lebar Karapas dan Bobot Tubuh Rajungan (Portunus Pelagicus) Pada Zona Intertidal dan Zona Seagrass di Perairan Bungin Permai, Konawe Selatan, Sulawesi Tenggara Indonesia
}

\section{The Relationship between Carapace Width and Body Weight of Blue Swimming Crab in Intertidal and Seagrass Zones in Bungin Permai of South Konawe, Southeast Sulawesi, Indonesia}

\author{
Yustika Intan Permatahati ${ }^{\left.1)^{*}\right)}$, La Sara ${ }^{2)}$, Yusnaini ${ }^{3)}$ \\ ${ }^{1)}$ Program Studi Ilmu Perikanan Pascasarjana Universitas Halu Oleo, Kendari, Indonesia. \\ ${ }^{2)}$ Program Studi Manajemen Sumberdaya Perairan Fak. Perikanan dan Ilmu Kelautan Universitas Halu Oleo, Kendari, Indonesia. \\ ${ }^{3)}$ Program Studi Budidaya Perairan Fak. Perikanan dan Ilmu Kelautan, Kendari, Indonesia. \\ Corresponding author ${ }^{*}$ : intanintanaa@gmail.com
}

\begin{abstract}
The aim of this study was analyze the relationship between carapace width and body weight of blue swimming crab in intertidal and seagrass zones in Bungin Permai of South Konawe. The blue swimming crab samples were taken using collapsible trap by size of $(53 \times 40 \times 25) \mathrm{cm}$ which was covered by nylon net of 1.5 inch mesh size. The traps used were 50 units. All samples were identified their sexes, measured their carapace width $(\mathrm{CW})$ using caliper $(0.1 \mathrm{~mm})$, and weighed their body weight $(\mathrm{W})$ using electronic balance $(1 \mathrm{~g})$. Total samples obtained were 162 individuals which consisted of 89 males (54.93\%) and 73 females (45.06\%). The relationship between CW and $\mathrm{W}$ of those blue swimming crabs was analyzed using a linear regression. The results of study showed that the relationship between $\mathrm{CW}$ and $\mathrm{W}$ of blue swimming crab males in intertidal and seagrass zones followed the equation of $\mathrm{W}=4.771(\mathrm{CW})^{3.2648}(\mathrm{r}=0.9643)$ and $\mathrm{W}=4.4673(\mathrm{CW})^{3.1273}(\mathrm{r}=0.9654)$, respectively, while blue swimming crab females in the same zones followed the equation of $\mathrm{W}=4.3097(\mathrm{CW})^{3.0168}(\mathrm{r}=0.9349)$ and $\mathrm{W}=$ $3.8177(\mathrm{CW})^{2.7689}(\mathrm{r}=0.9407)$, respectively. Those data imply that there are strong correlation between $\mathrm{CW}$ and $\mathrm{W}$ of blue swimming crab with growth patterns are relatively similar.
\end{abstract}

Keywords: Portunus pelagicus, carapace widt and body weight relationship, intertidal zone, seagrass zone

\begin{abstract}
ABSTRAK
Tujuan penelitian ini adalah untuk menganalisis hubungan lebar karapas dan bobot tubuh rajungan pada zona berbeda (intertidal dan seagrass zone) di perairan Bungin Permai Konawe Selatan. Pengambilan sampel rajungan dilakukan menggunakan alat tangkap bubu lipat ukuran $(53 \times 40 \times 25) \mathrm{cm}$ dengan ukuran mata jaring 1,5 inchi sebanyak 50 unit. Seluruh sampel yang diperoleh diidentifikasi jenis kelaminnya, diukur lebar karapasnya (CW) menggunakan kaliper ketelitian $0,1 \mathrm{~mm}$, dan ditimbang bobotnya $(\mathrm{W})$ menggunakan electronic balance ketelitian 1 g. Untuk mengetahui hubungan $\mathrm{CW}$ dan $\mathrm{W}$ rajungan digunakan analisis regeresi. Sampel yang diperoleh berjumlah 162 individu yang terdiri atas 89 individu jantan $(54,93 \%)$ dan 73 individu betina $(45,06 \%)$. Hubungan $\mathrm{CW}$ dan $\mathrm{W}$ rajungan tersebut dianalisis menggunakan regresi linear. Hasil analisis menunjukan persamaan regresi rajungan jantan pada zona intertidal dan seagrass masing-masing adalah $\mathrm{W}=4,771(\mathrm{CW})^{3,2648}(\mathrm{r}=0,9643)$ dan $\mathrm{W}$ $=4,4673(\mathrm{CW})^{3,273}(\mathrm{r}=0,9654)$, sedangkan rajungan betina pada zona intertidal dan seagrass masing-masing adalah $\mathrm{W}=4,3097(\mathrm{CW})^{3.0168}(\mathrm{r}=0,9349)$ dan $\mathrm{W}=3,8177(\mathrm{CW})^{2,7689}(\mathrm{r}=0,9407)$. Data tersebut menjelaskan bahwa terdapat hubungan yang kuat antara $\mathrm{CW}$ dan $\mathrm{W}$ rajungan dengan pola pertumbuhan relatif sama pada kedua zona penelitian.
\end{abstract}


Kata kunci: Portunus pelagicus, hubungan lebar karapas dan bobot tubuh, zona intertidal, zona seagrass

\section{DOI: http://dx.doi.org/10.33772/jspi.v3n1.}

\section{PENDAHULUAN}

Rajungan (blue swimming crab merupakan sumberdaya perikanan yang mempunyai nilai ekonomis penting untuk dikembangkan.. Lokasi penangkapan (fishing ground) rajungan di Sulawesi Tenggara tersebar hampir di seluruh perairan pesisir, seperti di Selat Tiworo, Teluk Lasongko, perairan Pulau Kabaena dan lain-lain. Salah satu daerah penangkapan rajungan di Konawe Selatan adalah di perairan Bungin Permai yang merupakan bagian dari perairan Selat Tiworo.

Sampai saat ini komoditas rajungan masih mengandalkan hasil penangkapan dari laut dan belum bisa disuplai dari hasil budidaya. Tingginya nilai ekonomis komoditas ini telah memicu berkembangnya usaha baik dalam penangkapan maupun pengolahannya. Dalam bidang penangkapan, berkembang beberapa usaha penangkapan rajungan menggunakan beberapa jenis alat tangkap utama, yaitu bubu, jaring kejer dan garok rajungan. Masingmasing alat tersebut memiliki selektivitas berbeda terhadap ukuran rajungan hasil tangkapan. Dalam bidang pengolahan saat ini berkembang pesat usaha pengupasan rajungan yang dilakukan oleh para pengumpul yang bekerjasama dengan perusahaan besar dengan membuat miniplant di sentra-sentra produksi rajungan.

Secara komersial ukuran rajungan menjadi salah satu penentu dalam menetapkan harga komoditas ini. Harga daging rajungan bervariasi dan bergantung pada ukuran dan komposisi daging pada bagianbagian tubuhnya. Daging termahal adalah bagian pangkal kaki renang. Daging bagian ini yang utuh dan memiliki berat lebih dari $10 \mathrm{~g}$ berharga Rp. $200.000 / \mathrm{kg}$ pada tingkat pengumpul. Kondisi daging seperti ini dikategorikan sebagai daging jumbo. Ukuran rajungan yang kecil akan menghasilkan jumlah daging yang sedikit dan harga yang relatif rendah.

Secara biologis ukuran panjang, lebar dan bobot rajungan menjadi salah satu faktor penting untuk diketahui. Melalui pengetahuan tentang ukuran tiap individu maka dapat diketahui variabilitas ukuran dalam suatu populasi rajungan. Dengan demikian dapat diketahui suatu populasi berasal dari kelompok umur (kohort) yang sama atau berbeda. Secara individu pengetahuan tentang panjang, lebar dan bobot serta korelasinya masing-masing dapat menentukan tingkat kemontokannya. Rajungan dengan kecepatan pertambuhan bobot lebih tinggi dibandingkan dengan kecepatan pertambahan panjangnya mencirikan bahwa rajungan tersebut tergolong montok/gemuk dan sebaliknya tergolong kurus. Selain untuk mengetahui kemontokan rajungan, ukuran panjang juga dapat digunakan dalam menentukan selektivitas alat tangkap. Dalam menentukan selektivitas alat tangkap pada ukuran tertentu, maka ukuran panjang rajungan menjadi salah satu faktor yang dipertimbangkan untuk menentukan lebar mata jaring atau bukaan mulut bubu. Analisa mengenai hubungan lebar karapas dan bobot tubuh dapat digunakan untuk mempelajari pola pertumbuhan. Untuk mengetahui pola hubungan lebar karapas dan bobot rajungan serta mengetahui kemontokannya maka penelitian ini penting dilakukan. Tujuan penelitian ini adalah untuk menganalisis hubungan lebar karapas (CW) dan bobot tubuh (W) rajungan pada zona intertidal dan seagrass di perairan Bungin Permai Konawe Selatan.

\section{METODE PENELITIAN}

Penelitian ini dilaksanakan di perairan Bungin Permai Konawe Selatan pada zona intertidal dan seagrass (Gambar 1). Penelitian ini dilakukan selama 6 bulan. Pengambilan sampel rajungan menggunakan bubu lipat persegi empat dengan ukuran $(53 \times 40 \times 25$ $\mathrm{cm}$ ) dan ukuran mata jaring 1,5 inch sebanyak 50 unit/stasiun. Pemasangan bubu dilakukan pada saat air menjelang pasang dan diangkat ketika air menjelang surut.Sampel rajungan yang diperoleh dikelompokan berdasarkan jenis kelamin jantan dan betina.Setiap individu rajungan tersebut diukur lebar karapasnya (Gambar 2) menggunakan kaliper ketelitian 0,1 mm dan ditimbang bobotnya menggunakan electronic balance ketelitian $1 \mathrm{~g}$.

Hubungan $\mathrm{CW}$ dan $\mathrm{W}$ rajungan dianalisis menggunakan persamaan berikut (Balasubramanian dan Suseelan, 1998, Tongdee, 2001; Kamrani et al, 2010; La Sara, 2001), yaitu: 


$$
\mathbf{W}=\mathbf{a L}^{\mathbf{b}}
$$

dimana: $\mathrm{W}=$ bobot total tubuh $(\mathrm{g}), \mathrm{L}=$ panjang karapas horizontal $(\mathrm{mm})$, dan a dan $\mathrm{b}=$ konstanta

Persamaan tersebut dapat dilogaritmakan menjadi persamaan regresi linier sederhana(George et al, 1986), yaitu:

\section{$\log W=\log a+b \log L$.}

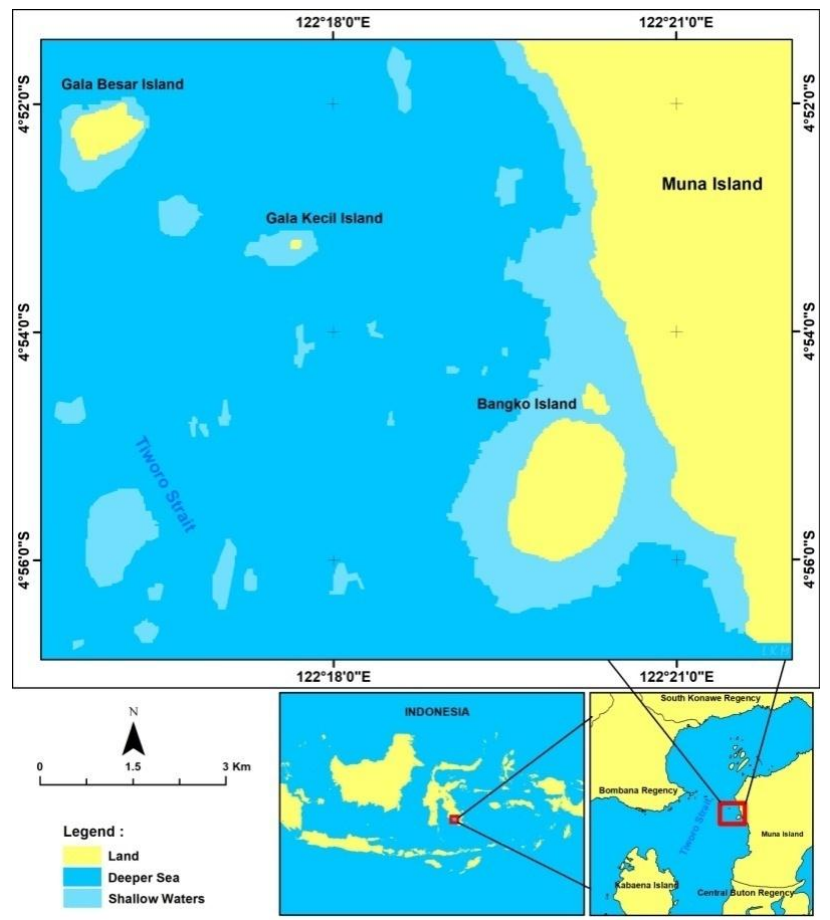

Gambar 1. Peta lokasi pengambilan sampel di perairan Bungin Permai, Konawe Selatan

Untuk mengetahui nilai $\mathrm{b}=3$ atau $\mathrm{b} \neq 3$ maka dilakukan uji statistik (uji-t). Apabila nilai $b=3$, maka pola pertumbuhannya bersifat isometrik yaitu pertambahan $\mathrm{CW}$ seimbang dengan pertambahan $\mathrm{W}$ rajungan, namun apabila nilai $\mathrm{b} \neq 3$, maka pola pertumbuhannya bersifat allometrik, yaitu pertambahan $\mathrm{CW}$ tidak seimbang dengan pertambahan W. Pola pertumbuhan allometrik negatif jika $\mathrm{b}<3$, sedangkan pola pertumbuhan allometrik positif jika $b>3$.

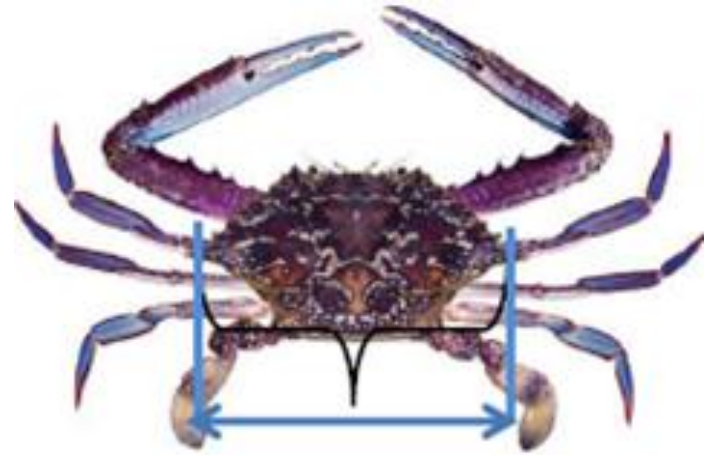

Gambar 2. Metode pengukuran lebar karapas rajungan (Permen KP, 2016)

\section{Hasil \\ Komposisi Ukuran}

\section{HASIL DAN PEMBAHASAN}

Jumlah total rajungan sampel sebanyak 162 ekor terdiri dari 89 ekor $(54,93 \%)$ jantan dan 73 ekor $(45,06 \%)$ betina. Kisaran CW rajungan berfluktuasi tiap bulan. Secara keseluruhan $\mathrm{CW}$ rajungan jantan terendah $50,95 \mathrm{~mm}$ dan tertinggi $140,95 \mathrm{~mm}$, sedangkan CW betina terendah 47,12 $\mathrm{mm}$ dan tertinggi $161,3 \mathrm{~mm}$. Data yang sama juga ditunjukan oleh $\mathrm{W}$ rajungan jantan dan betina yang bervariasi sangat luas. Rajungan jantan yang mempunyai $\mathrm{W}$ terendah adalah $7 \mathrm{~g}$ dan tertinggi $255 \mathrm{~g}$, sedangkan rajungan betina yang mempunyai $\mathrm{W}$ terendah $7 \mathrm{~g}$ dan tertinggi $237 \mathrm{~g}$ (Tabel 1).

Tabel 1. Kisaran ukuran lebar karapas rajungan jantan dan betina di perairan Bungin Permai, Konawe Selatan

\begin{tabular}{|c|c|c|c|c|}
\hline No. & Lokasi & $\begin{array}{c}\text { Jenis } \\
\text { Kelamin }\end{array}$ & $\begin{array}{c}\text { Kisaran } \\
\text { Ukuran Lebar } \\
\text { Karapas } \\
(\mathrm{mm})\end{array}$ & $\begin{array}{c}\text { Kisaran } \\
\text { Ukuran } \\
\text { Bobot } \\
\text { Tubuh }(\mathrm{g})\end{array}$ \\
\hline \multirow[t]{2}{*}{1} & $\begin{array}{l}\text { Intertidal } \\
\text { zone }\end{array}$ & Jantan & $\begin{array}{l}52,26- \\
140,95\end{array}$ & $7-255$ \\
\hline & & Betina & $\begin{array}{l}70,09- \\
130,57\end{array}$ & $15-131$ \\
\hline \multirow[t]{2}{*}{2} & $\begin{array}{l}\text { Seagrass } \\
\text { zone }\end{array}$ & Jantan & $\begin{array}{l}50,95- \\
121,47\end{array}$ & $7-118$ \\
\hline & & Betina & $\begin{array}{l}47,12- \\
120,83\end{array}$ & $7-98$ \\
\hline
\end{tabular}

\section{Hubungan Lebar Karapas dan Bobot Tubuh}

Secara spesifik, hubungan $\mathrm{CW}$ dan $\mathrm{W}$ rajungan jantan dan betina pada zona intertidal dan seagrass masing-masing disajikan pada Gambar 3 dan 4. 
4 Yustika Intan Permatahati et al.

JURNAL SAINS dan INOVASI PERIKANAN / Journal of Fishery Science and Innovation

Vol. 3, No. 1, 1-8, Januari 2019
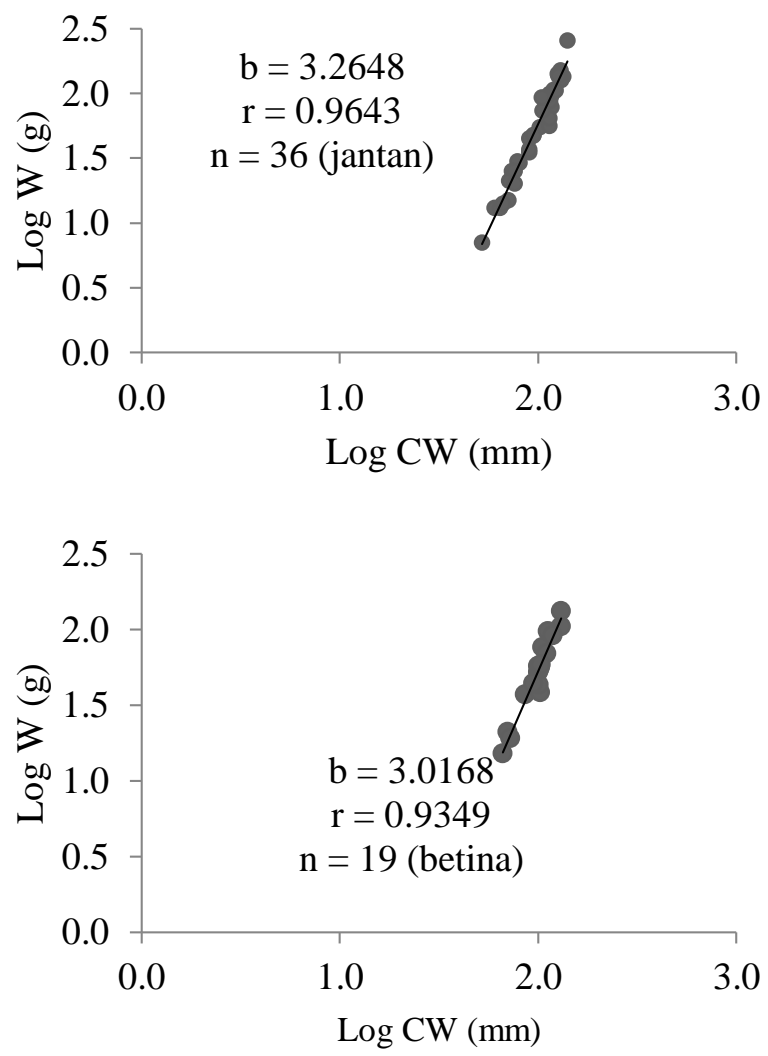

Gambar 3. Hubungan lebar karapas (CW) dan bobot tubuh (W) rajungan pada zona intertidal di perairan Bungin Permai, Konawe Selatan

Hubungan $\mathrm{CW}$ dan $\mathrm{W}$ rajungan jantan dan betina pada zona intertidal masing-masing memiliki korelasi yang kuat $(0,964$ dan 0,934$)$.

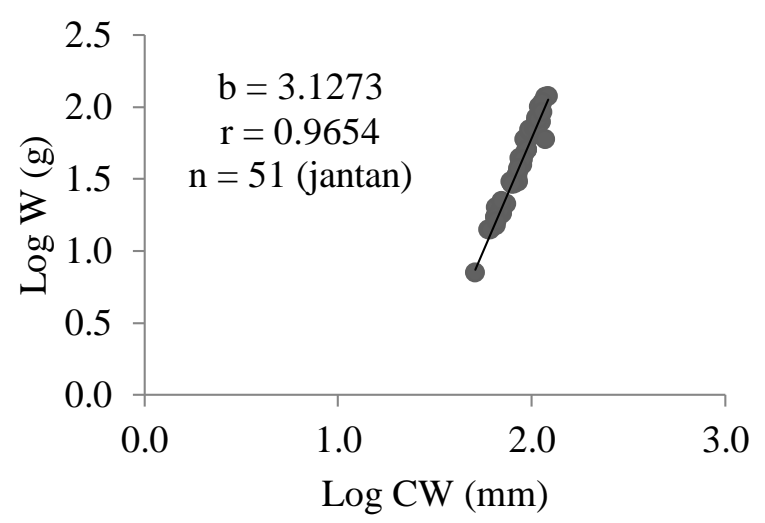

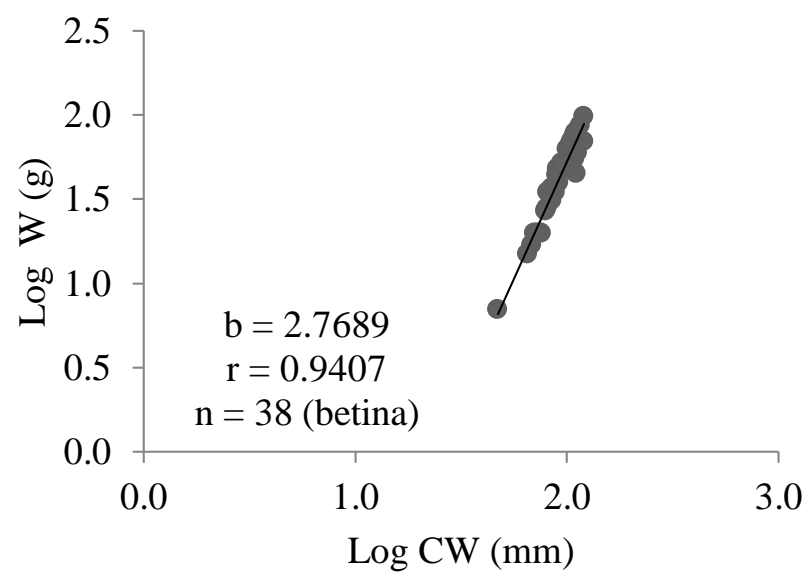

Gambar 4. Hubungan lebar karapas (CW) dan bobot tubuh (W) rajungan pada zona seagrass di perairan Bungin Permai, Konawe Selatan

Tabel 2. Pola pertumbuhan rajungan pada masingmasing zona

\begin{tabular}{ccccc}
\hline \multirow{2}{*}{ Zona } & \multicolumn{2}{c}{ Nilai b } & \multicolumn{2}{c}{ Pola Pertumbuhan } \\
& Jantan & Betina & Jantan & Betina \\
\hline Intertida & 3,2648 & 3,0168 & isometrik & isometrik \\
1 & & & & \\
Seagrass & 3,1273 & 2,7689 & isometrik & isometrik \\
\hline
\end{tabular}

Rajungan yang diperoleh menunjukan variasi CW dan W (Tabel 1). Variasi ukuran rajungan menunjukan bahwa terdapat struktur umur yang bervariasi dalam satu populasi rajungan (Sunarto, 2007). Besarnya variasi ini juga menunjukan bahwa rajungan yang tertangkap tidak dihasilkan dari satu kohort yang sama. Keadaan ini dapat mengindikasikan bahwa rajungan di perairan ini memijah tidak dalam satu waktu yang sama.

Rajungan memiliki pergerakan yang luas sehingga dapat ditemukan pada berbagai habitat, termasuk daerah alga atau padang lamun dengan substrat lumpur atau pasir mulai dari daerah intertidal sampai pada kedalaman 50 m (Williams, 1982; Edgar 1990). Umumnya, rajungan juvenil lebih banyak ditemukan di perairan dangkal, sedangkan yang dewasa secara komparatif banyak ditemukan di perairan yang lebih dalam. Ukuran juvenil dapat ditemukan di sekitar daerah intertidal dekat hutan mangrove dengan substrat lumpur pada usia $8-12$ bulan ketika mencapai ukuran lebar karapas 80 - 100 mm (Smith, 1982; La Sara et al., 2016). 


\section{Hubungan Lebar Karapas dan Bobot Tubuh}

Hubungan $\mathrm{CW}$ dan $\mathrm{W}$ rajungan pada masingmasing zona (Gambar 3 dan 4) menunjukan pola pertumbuhan isometrik. Hubungan $\mathrm{CW}$ dan $\mathrm{W}$ menggambarkan sifat pertumbuhan. Nilai $b$ dalam persamaan tersebut menunjukan pola pertumbuhan isometrik (Tabel 2), berarti pertambahan $\mathrm{CW}$ seimbang dengan pertambahan $\mathrm{W}$ tubuh. Nilai koefisien $\mathrm{b}$ tersebut menunjukan rasio kecepatan pertumbuhan antara CW dan W (Sunarto et al., 2010). Pola pertumbuhan lainnya disebut pertumbuhan allometrik (positif atau negatif) yang menunjukan pertambahan $\mathrm{CW}$ tidak seimbang dengan pertambahan $\mathrm{W}$ tubuhnya.

Secara keseluruhan, hubungan $\mathrm{CW}$ dan W rajungan jantan dan betina di perairan Bungin Permai menunjukan pola pertumbuhan isometrik. Pola pertumbuhan pada rajungan jantan menunjukan pertambahan 1 unit CW diikuti dengan 3,1675 pertambahan $\mathrm{W}$, sedangkan rajungan betina menunjukan pertambahan 1 unit $\mathrm{CW}$ diikuti dengan 3,0298 pertambahan W. Pertambahan ukuran CW rajungan ini akan terus terjadi sampai mencapai batas ukuran maksimum $\left(\mathrm{CW}_{\infty}\right)$. Pada saat itu ukuran $\mathrm{CW}$ tidak lagi bertambah namun $\mathrm{W}$ masih bisa bertambah atau berkurang tergantung dari faktor dalam maupun luar tubuhnya. Hubungan antara $\mathrm{CW}$ dan $\mathrm{W}$ dalam organism perairan umumnya merupakan akibat langsung dari respon terhadap lingkungan (Turra et al., 2002).

Hasil analisis statistik hubungan $\mathrm{CW}$ dan W rajungan masing-masing jenis kelamin jantan dan betina dari kedua zona penelitian diperoleh persamaan regresi dengan nilai koefisien korelasi ( $r$ ) yang sangat kuat mendekati satu, yaitu 0,96 dan 0,93 (zona intertidal) dan 0,96 dan 0,94 (zona seagrass). Data ini menunjukan bahwa hubungan $\mathrm{CW}$ dan $\mathrm{W}$ rajungan jantan dan betina, walaupun lokasi berbeda, menunjukan korelasi kuat.

Kangas (2000) dalam penelitiannya di perairan Australia Barat memperoleh nilai $b$ yang lebih besar untuk rajungan jantan disbanding betina, masingmasing yaitu 3,260 dan 3,056. Sunarto (2012) di perairan Brebes Indonesia menemukan nilai $b$ pada rajungan jantan lebih besar dibandingkan betina, masing-masing yaitu 3,0405 dan 2,8813, sedangkan Basri (2014) dalam penelitiannya di perairan Toronipa, Sulawesi Tenggara Indonesia menemukan hal yang berbeda, yaitu nilai $b$ jantan lebih kecil dibandingkan betina masing-masing yaitu 2,7031 dan
2,8267. Walaupun demikian, perbedaan ini tidak signifikan. Perbedaan nilai $\mathrm{b}$ tersebut tidak hanya terjadi pada rajungan, tetapi spesies crustacean lainnya seperti Portunus sanguinolentus memiliki nilai b yang lebih besar pada jantan disbanding betina, masing-masing yaitu 3,122 dan 3,054 (Dineshbabu et al, 2007). Pada kepiting bakau (Scylla serrata) menunjukan nilai masing-masing yaitu 2,952 dan 1,688 (La Sara et al., 2002) (Tabel 3).

Perbedaan pola pertumbuhan rajungan pada masing-masing lokasi tersebut terjadi karena perbedaan kondisi perairan, ketersediaan makanan, perbedaan metode koleksi, dan jumlah sampel. La Sara et al, (2002) menyatakan bahwa pola pertumbuhan crustasea secara umum bervariasi antara genus dan spesies, masing-masing memiliki pola pertumbuhan yang khas. Hal ini diduga tergantung pada habitat spesies dan variasi geografis antar populasi atau karena eksploitasi perikanan (Branco and Fracasso, 2004). Hartnoll (1982) dan Araujo and Lira (2012) menyatakan bahwa perbedaan tersebut dapat disebabkan faktor luar yakni adanya perbedaan iklim mikro yang optimum seiring perubahan musim dan jumlah makanan, serta faktor dalam yakni jenis kelamin, tingkat kedewasaan dan anggota tubuh yang hilang.

Berdasarkan nilai $b$ yang diperoleh dalam penelitian ini, menunjukan bahwa rajungan jantan lebih besar dibandingkan betina. Razek et al (2006) menyatakan bahwa umumnya rajungan jantan memiliki bobot tubuh yang lebih berat disbanding betina, karena betina lebih banyak mengeluarkan energy untuk reproduksi, sedangkan penggunaan energy pada jantan lebih banyak dimanfaatkan untuk pertumbuhan. Sugilar et al (2012) menyatakan bahwa kepiting jantan umumnya memiliki laju pertumbuhan yang lebih cepat disbanding betina. Perbedaan laju pertumbuhan ini dapat disebabkan oleh berbagai faktor, antara lain kompetisi, mortalitas dan rekruitmen. Sugilar et al (2012) mengasumsikan bahwa laju pertumbuhan rajungan betina yang cenderung lambat disbanding jantan berhubungan dengan tingkat kematangan dan pemijahan, yakni rajungan betina ketika akan memasuki musim pemijahan lebih banyak diam (tidak aktif bergerak) dan menyimpan energinya untuk reproduksi. Dixon and Hooper (2009) menyatakan bahwa rajungan akan cenderung mengurangi aktivitasnya selama musim dingin. 
Yustika Intan Permatahati et al.

JURNAL SAINS dan INOVASI PERIKANAN / Journal of Fishery Science and Innovation

Vol. 3, No. 1, 1-8, Januari 2019

Tabel 3.Hubungan lebar karapas dan bobot tubuh beberapa spesies kepiting di lokasi berbeda

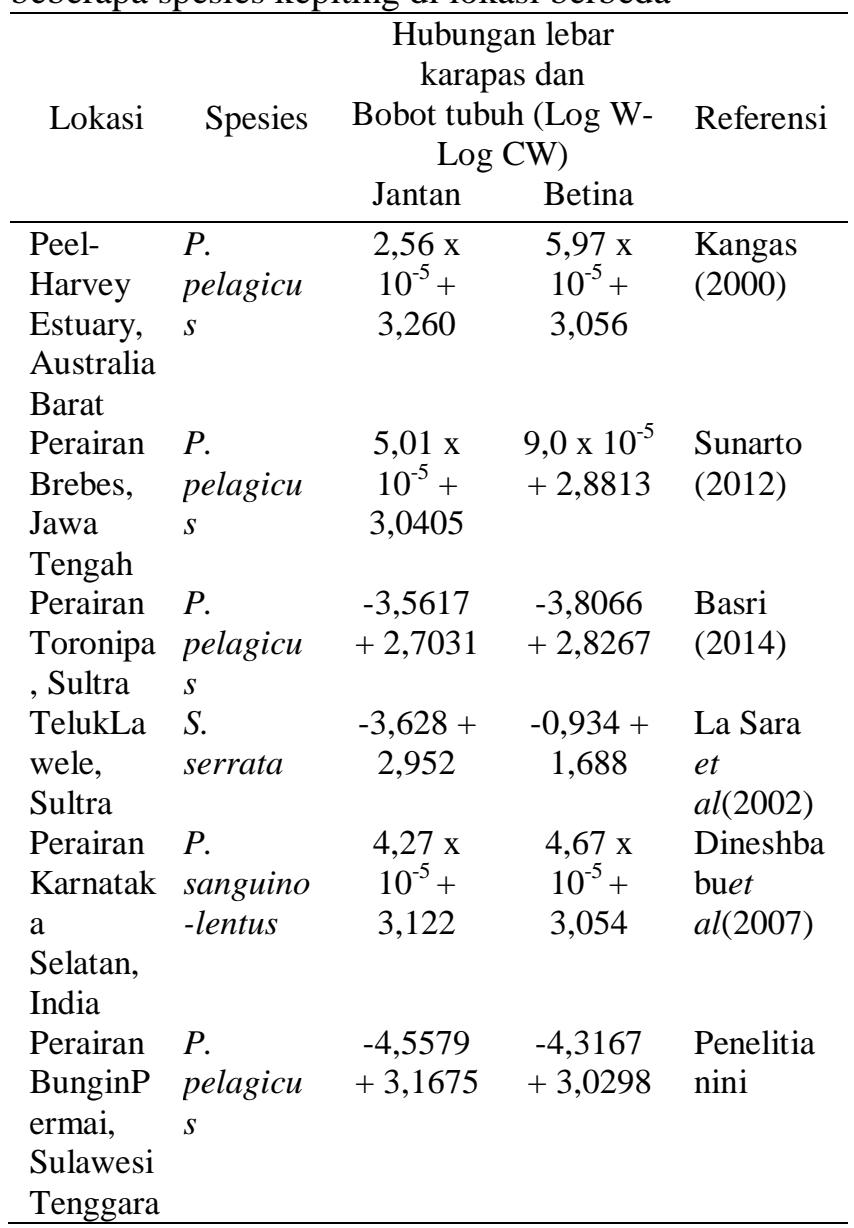

Penyebab lain terkait perbedaan laju pertumbuhan rajungan jantan dan betina dipengaruhi kondisi fisik lingkungan seperti temperatur yang mempengaruhi laju pertumbuhan kepiting ataupun invertebrate lainnya (Longhurst and Pauly, 1987; Cadman and Weinstein, 1988; Hartnoll, 2001). Sugilar et al, (2012) menyatakan bahwa variasi temperature berperan penting terhadap laju pertumbuhan yang menyokong aktivitas reproduksi Portunus trituberculatus di perairan Korea bagian barat. Umumnya ketika temperature meningkat maka akan menyebabkan laju pertumbuhan yang lebih cepat. Odum (1971) menjelaskan bahwa ketika terjadi peningkatansuhu $10^{\circ} \mathrm{C}$, maka proses metabolisme di dalam tubuh organism akan bekerja 2 kali lebih cepat dari semula.

Daerah-daerah yang memiliki pola musim fluktuatif (temperate atau subtropic), perubahan musim merupakan faktor yang sangat mempengaruhi laju pertumbuhan tersebut, sebaliknya di daerah tropis kondisi demikian tidak berpengaruh. Smith (1982) menjelaskan hasil pengamatannya di Australia Selatan, $P$. pelagicus memiliki ketertarikan yang jelas terhadap daerah tropis atau daerah subtropics ketika musim panas karena adanya peningkatan temperatur air yang memungkinkan reproduksi dan pertumbuhan terjadi. Laju pertumbuhan ini selain bergantung pada temperature perairan juga bergantung pada ukuran (Meagher, 1971). Svane and Chesire (2005) menyatakan bahwa selama stadia juvenil, kepiting akan molting lebih sering (berkali-kali), sedangkan ketika dewasa kepiting hanya dapat molting satu atau dua kali dalam setahun. Di perairan Australia Selatan, pertumbuhan juvenile terbesar terjadi selama musim panas dan mulai melambat ketika musim dingin, musim gugur dan musim semi (Grove-Jones, 1987).

Penelitian mengenai pertumbuhan digunakan juga untuk menduga perubahan bentuk dan ukuran abdomen, pleopod dan cheliped pada masa ontogenik. Secara matematis, hubungan lebar karapas dan bobot tubuh ini dapat menjelaskan parameter biologi rajungan lainnya, seperti variasi pertumbuhan berdasarkan jenis kelamin, ukuran pertama matang kelamin, tingkat kematangan gonad dan musim pemijahan. Selain itu, informasi mengenai hubungan lebar karapas dan bobot tubuh penting diketahui agar dapat menduga komposisi ukuran suatu stok, khususnya untuk tujuan komersil (Oluwatoyinet al, 2013).

\section{KESIMPULAN}

Hubungan lebar karapas dan bobot tubuh rajungan jantan dan betina pada zona intertidal dan seagrass di perairan Bungin Permai masing-masing ditunjukan persamaan $\mathrm{W}=4,771(\mathrm{CW})^{3,2648}(\mathrm{r}=0,9643)$ dan $\mathrm{W}=$ $4,4673(\mathrm{CW})^{3,1273}(\mathrm{r}=0,9654)$, sedangkan rajungan betina pada zona intertidal dan seagrass masingmasing adalah $\mathrm{W}=4,3097(\mathrm{CW})^{3.0168} \quad(\mathrm{r}=0,9349)$ dan $\mathrm{W}=3,8177(\mathrm{CW})^{2,7689} \quad(\mathrm{r}=0,9407)$. Hubungan $\mathrm{CW}$ dan $\mathrm{W}$ sangat kuat (nilai $\mathrm{r}$ mendekati 1). Data tersebut menjelaskan juga bahwa pola pertumbuhan rajungan pada kedua zona tersebut mengikuti pola pertumbuhan isometrik $(b=3$ sesuai uji statistik).

Ucapan Terima Kasih : Penulis menyampaikan terima kasih kepada nelayan rajungan di Desa Bungin Permai, Konawe Selatan Indonesia yang telah 
membantu akomodasi dan menangkap rajungan selama penelitian.

\section{DAFTAR PUSTAKA}

Araujo MDSLCD, Lira, JJPRD. 2012. Condition factor and carapace width versus wet weight relationship in the swimming crab Callinectesdanae Smith 1869 (Decapoda: Portunidae) at the Santa Cruz Channel, Pernambuco State, Brazil. Nauplius, 20(1): 4150.

Balasubramanian CP, C. Suseelan. 1998. Reproductive biology of the female deepwater crab Charybdis smithii (Brachyura: Portuidae) from the Indian Seas. Asian Fisheries Science 10: 211-222.

Basri MI. 2014. Aspek biologi reproduksi sebagai dasar pengelolaan sumberdaya rajungan (Portunus pelagicus, LINN 1758) di Perairan Toronipa Kecamatan Soropia Kabupaten Konawe. Tesis. Program Pascasarjana Ilmu Perikanan Universitas Halu Oleo. Kendari. 123 hal.

Branco JO, Fracasso HAA. 2004. Biologia populacional de Callinectesornatus (Ordway) Penha, Santa Catarina, Brasil. Revista Brasileira de Zoologia 21(1): 91-96.

Cadman LR, Weinstein MP. 1988. Effects of temperature and salinity on the growth of laboratory reared juvenile blue crabs Callinectes sapidus Rathbun. Journal of Experimental Marine Biology and Ecology 121: 193-207.

Dineshbabu AP, Sreedhara B, Muniyappa Y. 2007. Fishery and stock assessment of Portunus sanguinolentus (Herbst) from South Karnataka Coast India. Journal Marine Biology Assessment India 49(2): 134-140.

Dixon CD, Hooprt GE. 2009. Blue crab (Portunus pelagicus) Fishery. Fishery Assessment Report to PIRSA Fisheries. SARDI Aquatic Sciences Publication No: F2007/000729-5. SARDI Research Report Series No. 361.70 p.

Edgar, GJ. 1990. Predator-Prey interactions in seagrass beds II. distribution in diet of the blue manna crab, Portunus pelagicus (L) at Cliff Head. Western Australia. Journal Experimental Marine Biology Ecology 139: 23-32.

George L, Unnithan GR, Gopakumar K. 1986. Morphometric measurentments as an indeks for estimating yield of meat in shell fishes (Crab, $S$. serrata Forskal). Fisheries Technology 23(2): $196-198$.

Grove-Jones R. 1987. Catch and effort in the South Australian blue crab (Portunus pelagicus) fishery. South Australia Department of Fisheries Report. 45 pp.

Hartnoll RG. 1982. Growth, In, Bliss, D.E., and Abele, L.G. eds. The biology of crustacea, embryology, morphology and genetics. Academic Press, New York. p 111-196.

Kamrani E, Sabili AN, Yahyavi M. 2010. Stock assessment and reproductive biology of the blue swimming crab Portunus pelagicus in Bandar Abbas Coastal Waters Northern Persian Gulf. Journal of the Persian Gulf (Marine Science) 1(2): 11-22.

Kangas MI. 2000. Synopsis of the biology and exploitation of the blue swimmer crab, Portunus pelagicus Linneaus in Western Australia. Fisheries Western Australia, Perth, Western Australia. Fisheries Research Report. (121). 22 pp.

La Sara. 2001. Habitat and some biological parameters of two species of mud crab Scylla in Southeast Sulawesi, Indonesia, pp. 341-346. In Procceding of the JSPS-DGHE International Symposium on Fisheries Science in Tropical Area. O. Carman, Sulistiono, A. Purbayanto, T. Suzuki, S. Watanabe and T. Arimoto (eds.). TUF International JSPS Project Vol. 10. Konan Minato-ku, Tokyo, Japan.

La Sara, Ingles, JA, Baldevarona RB, Aguilar RO, Laureta LV, Watanabe S. 2002. Reproductive biology of mud crab Scylla serrata in Lawele Bay, Southeast Sulawesi, Indonesia. Crustacean Fisheries. 88-95.

La Sara, Mustika WH, Astuti O, Safilu. 2016. The reproductive biology of blue swimming crab Portunus pelagicus in Southeast Sulawesi waters, Indonesia. AACL Bioflux 9(5): 11011112.

Longhurst AR, Pauly D. 1987. Ecology of tropical oceans. Academic Press. London. Pp: 407.

Meagher TD. 1971. Ecology of the crab Portunus pelagicus in South Western Australia. PhD Thesis, University of Western Australia. Australia. 232 p. 
Odum EP. 1971. Dasar-dasar ekologi. Diterjemahkan oleh Samingan Tjahjono dan B. Srigandono. Universitas Gadjah Mada. Yogyakarta. 697 hal.

Oluwatoyin A, Akintade A, Clarke E, Kusemiju V. 2013. A study of length-weight relationship and condition factor of west african blue crab (Callinectes pallidus) from Ojo Creek, Lagos, Nigeria. American Journal of Research Communication 1(3): 102-115.

Peraturan Menteri Kelautan Dan Perikanan Republik Indonesia Nomor 56/Permen-KP/2016 Tentang Larangan Penangkapan dan/atau Pengeluaran Lobster (Panulirus Spp.), Kepiting (Scylla Spp.), Dan Rajungan (Portunus Spp.) Dari Wilayah Negara Republik Indonesia. Jakarta

Razek FAA, Taha SM, Ameran AA. 2006. Population biology of the edible crab Portunus pelagicus (Linnaeus) from Bardawil Lagoon, Northern Sinai, Egypt. Egyptian Journal of Aquatic Research 32(1): 401-418.

Smith H. 1982. Blue crab in south australia-their status, potensial and biology. SAFIC, 6: 6-9.

Sugilar H, Park YC, Lee NH, Han DW, Han KN, 2012. Population dynamics of the swimming crab Portunus trituberculatus (Miers, 1876) (Brachyura, Portunidae) from the West Sea of Korea. International Journal of Oceanography and Marine Ecological System, 1(2): 36-49.

Sunarto. 2007. penetuan ukuran layak tangkap melalui analisis fekunditas rajungan (Portunus sp) di Perairan Brebes. Jurnal Akuatika 5(1): 39-50.

Sunarto, Soedharma D, Riani E, Martasuganda S. 2010. Performa pertumbuhan dan reproduksi rajungan (Portunus pelagicus) di Perairan Pantai Kabupaten Brebes. Omni-Akuatika 9(11): 75-82.

Sunarto. 2012. karakteristik bioekologi rajungan (Portunus pelagicus) di perairan laut Kabupaten Brebes. Thesis. Sekolah Pascasarjana Institut Pertanian Bogor. 147 hal.

Svane I, Chesire A. 2005. Fisheries biology and spatial modelling of the blue swimmer crab (Portunus pelagicus). Fisheries Research and Development Corporation. Australian Government. Project No.1998/116.

Tongdee N. 2001. Size distribution, sex ratio and size at maturity of mud crab (Scylla spp) in Ranong Province, Thailand. Asian Fisheries Science 14: 113-120.

Turra A, Branco JO, Suoto FX. 2002. Biology of the hermit crab Petrochirus Diogenes (Linnaeus,
1758) in Southern Brazil. Brasileria Zoology 19: 1043-1051.

Williams MJ. 1982. Natural food and feeding in the commercial sand crab Portunus pelagicus Linnaeus 1766 (Crustacea: Decapoda: Portunidae) in Moreton Bay Queensland. Journal of Experimental Marine Biology and Ecology 59(2-3): 165-176. 